\title{
STUDENTS' PERCEPTION TOWARDS ENGLISH TEACHING STIMULUS VARIATION SKILLS AT SMP KRISTEN RURUKAN
}

\author{
Pryske Pertiwi Lengkong, Noldy Pelenkahu, I. Javier C. Tuerah \\ English Education Department, Faculty of Languages and Arts, Universitas Negeri Manado \\ Tondano, Indonesia \\ Email address: pryskelengkong@gmail.com
}

\begin{abstract}
This research is conducted to identify and describe the students' perception towards English Teaching Stimulus Variation Skills at SMP Kristen Rurukan. The population of this research are ninth grade students of SMP Kristen Rurukan, consisting of 22 students from grade $9 \mathrm{~A}$ and 24 students from grade $9 \mathrm{~B}$. The method of data analysis is descriptive method and the writers use questionnaires to collect the data. The results of this research are among six indicators, there are five indicators which are voice variation, focusing, pausing, gesturing and movement shows that English teacher vary in teaching while one another indicator that is eye contact is less vary. Based on the results above, English teacher must improve the variety of teaching stimulus variation skills especially in terms of eye contact so that students pay more attention to the lesson and learning better. Teacher should also develop all the stimulus variation skills in order form a positive attitude of students and they also will love the English subject and won't feel bored but will be more participate in various learning processes. For students, it is necessary to pay more attention, so they can enjoy in learning English.
\end{abstract}

Keywords: $\quad$ Perception, Teaching, Stimulus Variation Skills.

\section{INTRODUCTION}

Learning is one of the most important and profoundly affecting our lives. We can learn wherever we are, whether at home, in association, or in school. But we may feel bored in learning, especially learning a foreign language such as English. According to Hampp, Paula L. (2019: 15) language is a tool for expressing yourself, a communication tool, and a means for social control.

Nowadays, English is very important to be learn because English is an international language that is generally used to communicate with people from abroad (J Tuilan, JIC Tuerah, 2018). The teachers give some materials about English lesson, but sometimes their ways of teaching make the students boring and think that English lesson is not interesting. Learning English will be fun if the teacher is also fun, both in material explanations and teaching stimulus variation. So, teachers should have a teaching variation in their teaching to make teaching-learning English more fun. One teacher may be dealing with hundreds of students every day, while another may be dealing with fewer students. It can be imagines how hard it is for the teachers who deal with many students every day, and they must assess each of the character aspects provide by the curriculum (Tania, Liando, 2018). 
The components of the skill of variability cluster in six parts, there are: voice variation, focusing, pausing, eye contact, gesturing and movement. What students' thinks towards their English teachers' stimulus variations is very important. In line with that statement, it is also involved as a part of ELT, there are some factors in teaching-learning process, which can influence the gaining of successful goals at schools. They are curriculum, materials, method teachers, students and facility (Mogea, 2019). From this problem, we know that the teachers need variation in teaching styles to make students enthusiastic to study English. One of the most important things is the teachers should use their skill of variability. So, it will be very helpful to encourage the students to learn English especially in language itself because Maru (2016:58) states that language is the most important aspect in the life of all human beings. So, in this research, the writers want to find out what the students' perception towards English teaching stimulus variation skills at SMP Kristen Rurukan.

\section{RESEARCH METHODOLOGY}

The writers use observation and questionnaires. The writers observe English teacher's teaching stimulus variation in classroom activities and questionnaires for that students. The method of data analysis is descriptive method, which is analyzing the data by illustrating the object of the research (Kristina Nike. A 2006:31). The population of this research is the students of ninth grade of SMP Kristen Rurukan. The sample of this study is 46 students taken from the population; 22 students from grade $9 \mathrm{~A}$ and 24 students from grade 9B.

\section{DATA COLLECTION}

The writers use questionnaires to collect the data. According to Arikunto (2002:128), a questionnaire is number of written questions that use to gather information from the respondents about themselves or other things to know.

The questionnaires consist of 18 items statements to be answers.

The table of indicators as follows:

\begin{tabular}{|c|c|c|c|c|}
\hline No. & Indicators & $\begin{array}{c}\text { Item } \\
+\end{array}$ & Item - & Total \\
\hline 1. & $\begin{array}{c}\text { Voice } \\
\text { variation }\end{array}$ & 1,2 & 3 & 3 \\
\hline 2. & Focusing & 4,7 & 6 & 3 \\
\hline 3. & Pausing & 5,8 & 9 & 3 \\
\hline 4. & Eye contact & $\begin{array}{l}10 \\
12\end{array}$ & 11 & 3 \\
\hline 5. & Gesturing & $\begin{array}{l}13, \\
14\end{array}$ & 15 & 3 \\
\hline 6. & Movement & $\begin{array}{l}16, \\
18\end{array}$ & 17 & 3 \\
\hline \multicolumn{4}{|c|}{ Total } & 18 \\
\hline
\end{tabular}

Based on "Teacher evaluation: Global perspectives and their implications for English language teaching A literature review" by Simon Borgin 2018, the writers use that reference as a guide-lines and arrange the questionnaires as follows:

\begin{tabular}{|l|l|}
\hline No. & \multicolumn{1}{|c|}{ Statements } \\
\hline 1. & $\begin{array}{l}\text { When explaining material, the teacher's } \\
\text { voice is very clear. }\end{array}$ \\
\hline 2. & $\begin{array}{l}\text { When explaining subject matter, the } \\
\text { teacher gives a different tone of voice. }\end{array}$ \\
\hline 3. & $\begin{array}{l}\text { English teacher explained the material } \\
\text { quickly. }\end{array}$ \\
\hline 4. & $\begin{array}{l}\text { The teacher taps the blackboard / table to } \\
\text { get students' attention. }\end{array}$ \\
\hline
\end{tabular}




\begin{tabular}{|c|c|}
\hline 5. & $\begin{array}{l}\text { When students start to make noise, the } \\
\text { teacher pauses until the students return to } \\
\text { order. }\end{array}$ \\
\hline 6. & $\begin{array}{l}\text { The teacher doesn't care about noisy } \\
\text { students. }\end{array}$ \\
\hline 7. & $\begin{array}{l}\text { The teacher deliberately says the wrong } \\
\text { word to attract students' attention. }\end{array}$ \\
\hline 8. & $\begin{array}{l}\text { The teacher provides an opportunity for } \\
\text { students to think for a moment when } \\
\text { given questions. }\end{array}$ \\
\hline 9. & $\begin{array}{l}\text { The teacher urges students to } \\
\text { immediately answer the questions given. }\end{array}$ \\
\hline 10. & $\begin{array}{l}\text { When teaching in class, the teacher looks } \\
\text { at students without picking. }\end{array}$ \\
\hline 11. & $\begin{array}{l}\text { When explaining the material, the } \\
\text { teacher's view is more on the book / } \\
\text { board. }\end{array}$ \\
\hline 12. & $\begin{array}{l}\text { The teacher looks at students in all } \\
\text { directions. }\end{array}$ \\
\hline 13. & $\begin{array}{l}\text { When explaining material, the teacher } \\
\text { raises / waved or raise hand or move } \\
\text { eyebrows. }\end{array}$ \\
\hline 14. & $\begin{array}{l}\text { When explaining, the teacher's gestures } \\
\text { are adjusted to the subject matter. }\end{array}$ \\
\hline 15. & The teacher teaches rigidly. \\
\hline 16. & $\begin{array}{l}\text { The teacher explains the material while } \\
\text { walking and going around the class. }\end{array}$ \\
\hline 17. & $\begin{array}{l}\text { The teacher sat in his chair while } \\
\text { explaining the material. }\end{array}$ \\
\hline 18. & $\begin{array}{l}\text { The teacher approaches the students and } \\
\text { sees the work / assignments made by } \\
\text { students. }\end{array}$ \\
\hline
\end{tabular}

\section{DATA ANALYSIS}

In analyzing the data, the writers use the formula percentage, the formula is according to Sudjana (2006:131)

$$
\mathrm{P}=\frac{\mathrm{f}}{\mathrm{n}} \times 100 \%
$$

$\mathrm{P}=$ percentage

$\mathrm{f}=$ total number of respondents' answer

$\mathrm{n}=$ total number of respondents

\section{RESULTS OF THE STUDY}

Table of Raw Data

\begin{tabular}{|c|c|c|c|c|c|}
\hline 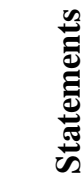 & 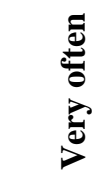 & 률 & 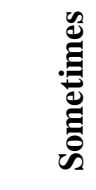 & 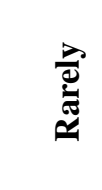 & $\frac{\grave{d}}{\grave{z}}$ \\
\hline 1 & 28 & 15 & 3 & 0 & 0 \\
\hline 2 & 4 & 20 & 15 & 7 & 0 \\
\hline 3 & 0 & 9 & 15 & 21 & 1 \\
\hline 4 & 1 & 10 & 22 & 11 & 2 \\
\hline 5 & 2 & 7 & 16 & 16 & 5 \\
\hline 6 & 0 & 1 & 4 & 11 & 30 \\
\hline 7 & 0 & 6 & 12 & 13 & 15 \\
\hline 8 & 15 & 30 & 0 & 1 & 0 \\
\hline 9 & 0 & 2 & 24 & 14 & 6 \\
\hline 10 & 11 & 19 & 6 & 6 & 4 \\
\hline 11 & 4 & 6 & 22 & 10 & 4 \\
\hline 12 & 14 & 21 & 8 & 3 & 0 \\
\hline 13 & 3 & 10 & 16 & 9 & 8 \\
\hline 14 & 6 & 9 & 14 & 10 & 7 \\
\hline 15 & 0 & 1 & 2 & 11 & 32 \\
\hline 16 & 15 & 17 & 14 & 0 & 0 \\
\hline 17 & 0 & 6 & 21 & 14 & 5 \\
\hline 18 & 25 & 16 & 5 & 0 & 0 \\
\hline
\end{tabular}


The table above shows the raw data is found in this research, which then calculates the percentage item by item. Start from item 1.

1. When explaining material, the teacher's voice is very clear.

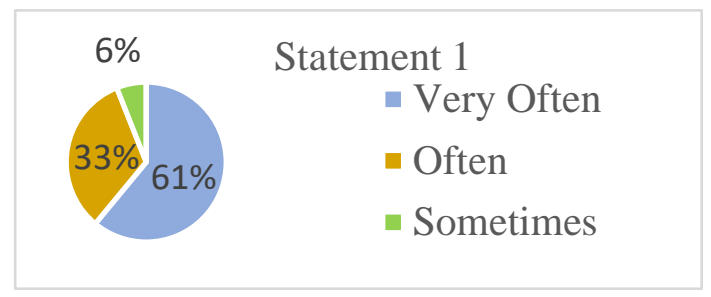

Based on the diagram above, $61 \%$ students answers "very often", 33\% answers "often", and 6\% answers 'sometimes'. It means that the voice of English teacher is varies greatly.

2. When explaining subject matter, the teacher gives a different tone of voice.

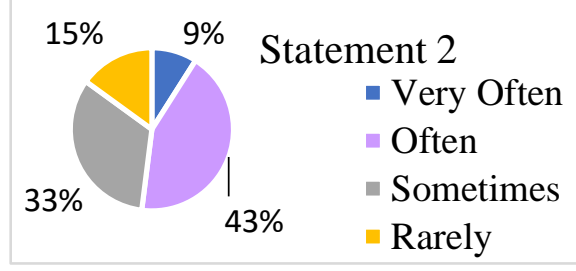

Based on the data above, 9\% students answer 'very often', $43 \%$ answers 'often', 33\% answers 'sometimes' and 9\% answers 'seldom'. It shows that English teacher often explains the material with different tone of voice.

\section{English teacher explains the material quickly.}

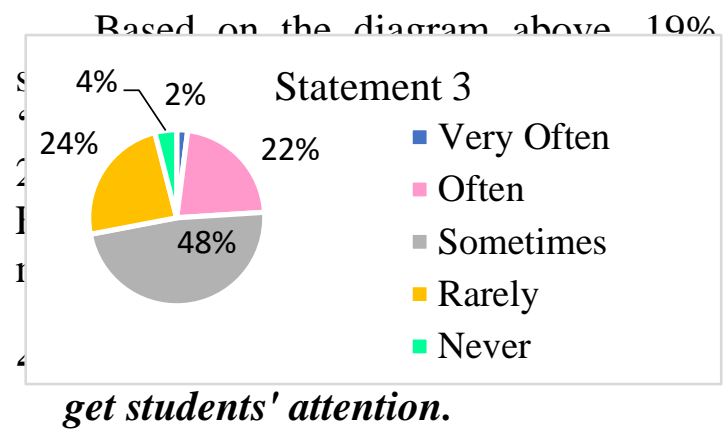

The data above shows that $2 \%$ students

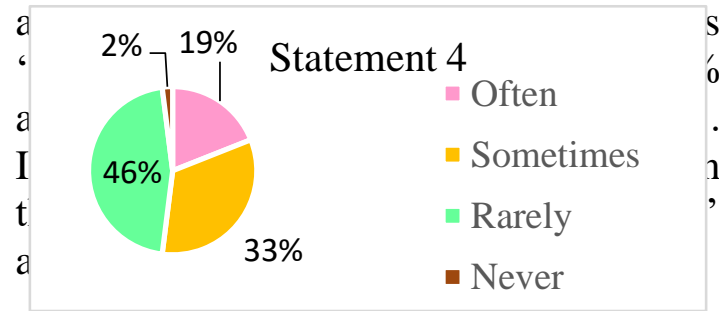

5. When students start to make noise, the teacher pauses until the students return to order.

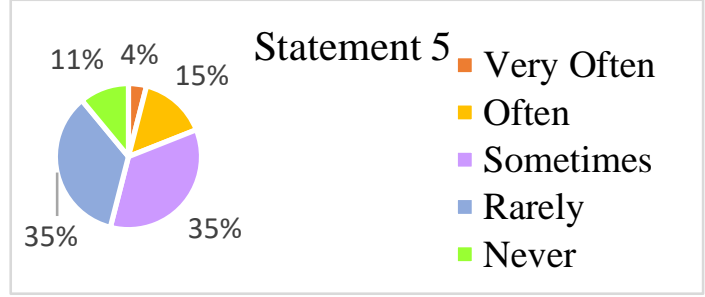

Based on the diagram, $4 \%$ student answers 'very often', $15 \%$ answers 'often', 35\% answers 'sometimes', 35\% answers 'seldom', and $11 \%$ answers 'never'. It can be concluded that sometimes the English teacher is quite for a moment until students' orderly. 
6. The teacher doesn't care about noisy students.

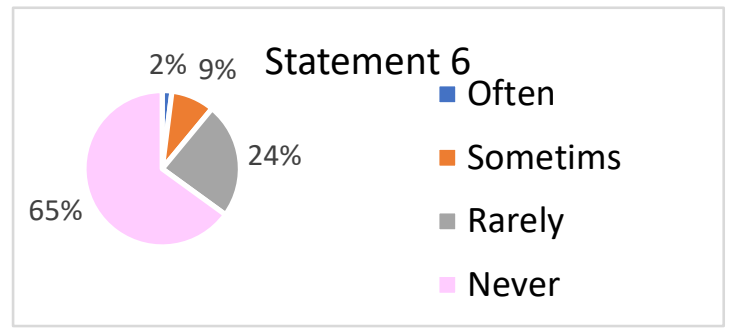

The diagram above shows that $2 \%$ students answers 'often', 9\% answers 'sometimes', 24\% answers 'seldom', and $65 \%$ answers 'never'. So, English teacher doesn't care about the noisy students it can be concluded never.

7. The teacher deliberately says the wrong word to attract students' attention.

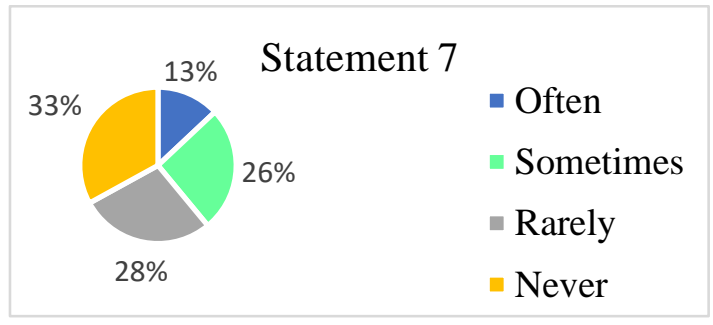

Based on the diagram above, $13 \%$ student answers 'often', 26\% answers 'sometimes', 28\% answers 'seldom', 33\% answers 'never'. It can be concluded that the English teacher never deliberately says the wrong words to attract students' attention.

8. The teacher provides an opportunity for students to think for a moment when given questions.

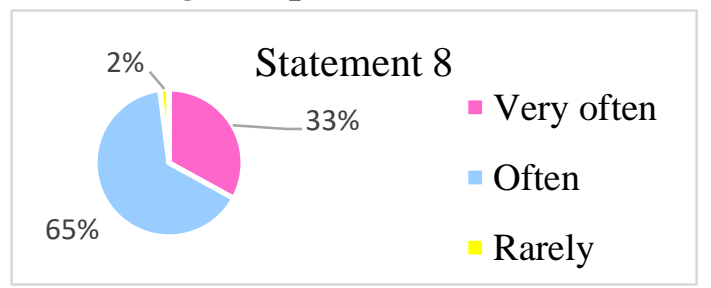

The diagram above shows that $33 \%$ students answers 'very often', 65\% answers 'often', $2 \%$ answers 'seldom'. So, the conclusion is the English teacher provides an opportunity for students to think for a moment when given questions.

\section{The teacher urges students to immediately answers the questions given.}

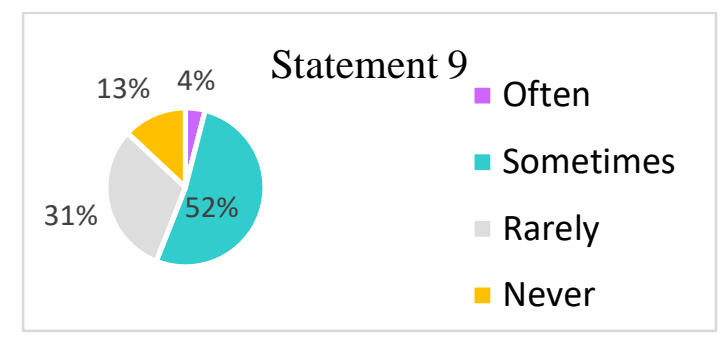

Based on the diagram above, $4 \%$ student answers 'often', $52 \%$ answers 'sometimes', 31\% answers 'seldom', 13\% answers 'never'. It can be concluded that the English teacher sometimes urges students to answer questions immediately.

10. When teaching at class, the teacher looks at students without picking.

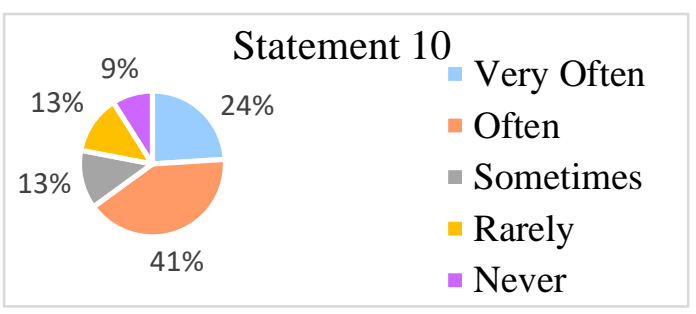

The diagram above shows that $24 \%$ students answers 'very often', 41\% answers 'often', $13 \%$ answers 'sometimes', 13\% answers 'seldom', 9\% answers 'never'. It shows that the English teacher often look at students without choosing. 
11. When explaining the material, the teacher's view is more on the book or board.

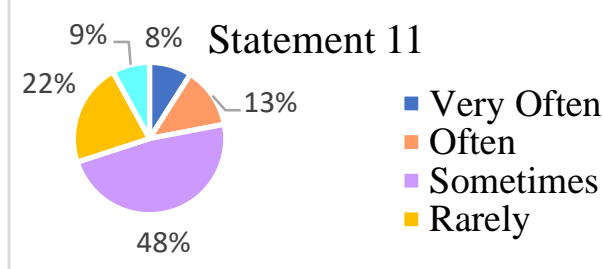

From the diagram above, $8 \%$ student answers 'very often', $13 \%$ answers 'often', 48\% answers 'sometimes', 22\% answers 'seldom', 9\% answers 'never'. So, when explaining the material, the viewpoint of the English teacher is sometimes more focused on the book or board.

\section{The teacher looks at students in all directions.}

\begin{tabular}{|c|c|}
\hline $17 \%$ & $\begin{aligned} \text { Statement } & 12 \\
& \text { Very Often } \\
& \text { Often } \\
& \square \text { Sometimes } \\
& \square \text { Rarely }\end{aligned}$ \\
\hline
\end{tabular}

The diagram above shows that $30 \%$ students answers 'very often', $46 \%$ answers 'often', $17 \%$ answers 'sometimes', 17\% answers 'seldom', 7\% answers 'never'. So, the conclusion is the English teacher often look at students in all directions.

\section{When explaining material, the teacher raises or waves hand or move eyebrows.}

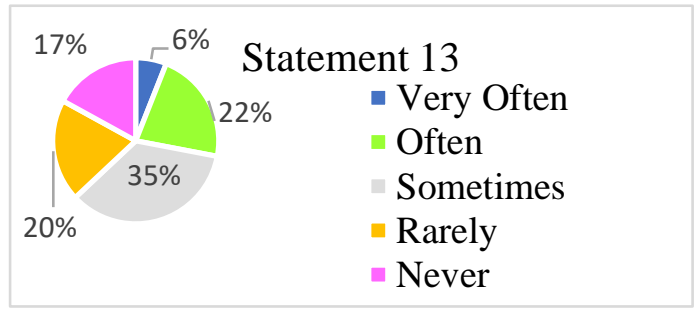

Based on the diagram above, $6 \%$ student says very often', $22 \%$ says 'often', $35 \%$ says 'sometimes', $20 \%$ says 'seldom, $17 \%$ says 'never'. It means that when explaining the material, English teacher sometimes raises or waves his or her hand or moves the eyebrows.

\section{When explaining, the teacher's gestures are adjust to the subject matter.}

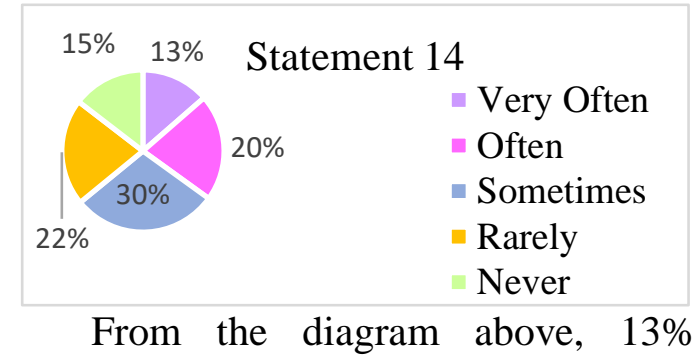
student answers 'very often', $20 \%$ answers 'often', 30\% answers 'sometimes'. 22\% answers 'seldom', 15\%answers 'never'. So, the conclusion is English teacher's body movements are sometimes adjusted to the subject matter.

\section{The teacher teaches rigidly.}

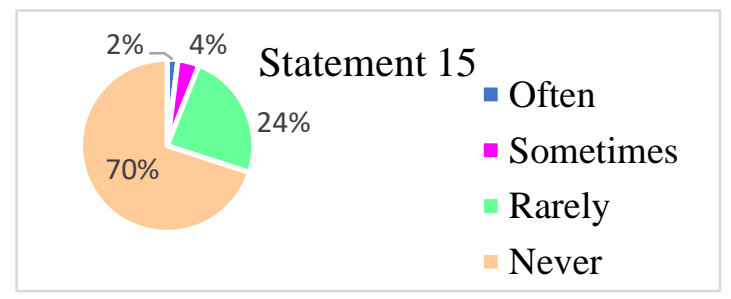

Based on the diagram above, $2 \%$ student says 'often', 4\%says 'sometimes', 24\%says 'seldom', 70\% says 'never'. It can be concluded that English teacher never teaches rigidly.

16. The teacher explains the material while walking and going around the class. 


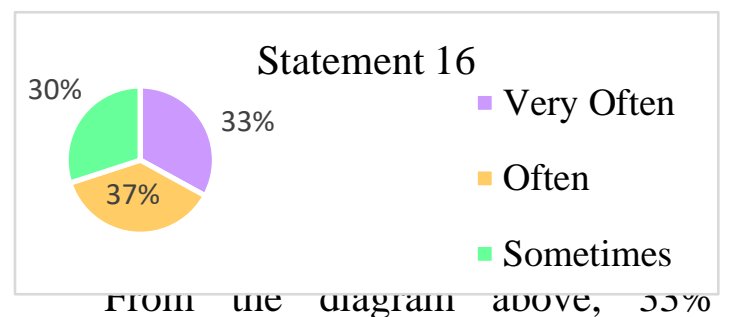

students answer 'very often', $37 \%$ answers 'often', 30\% answers 'sometimes'. So, the conclusion is English teacher often explains the material while walking around the classroom.

\section{The teacher sat in his chair while explaining the material.}

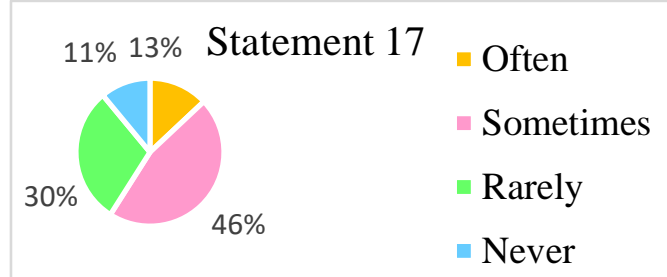

Based on the diagram above, $13 \%$ student says 'often', $46 \%$ says 'sometimes', 30\% says 'seldom', 11\% says 'never'. So, it can be concluded that sometimes the English teacher explains the material while sitting in a chair.

\section{The teacher approaches the students and sees the work or assignments made by students.}

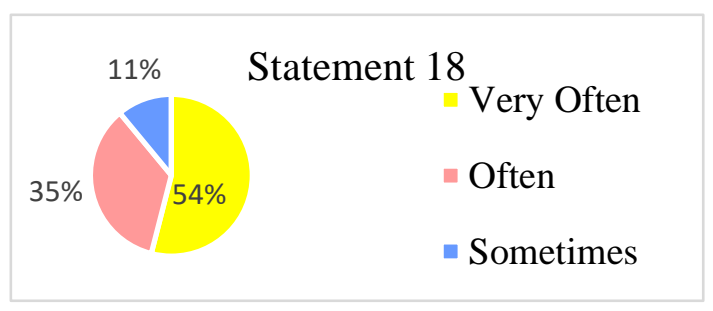

From the diagram above, 54\% students answer 'very often', 35\% students answer 'often', 11\% students answer 'sometimes'. So, it can be concluded that the English teacher often approaches and sees the assignments made by students.

\section{DISCUSSIONS}

From the findings data above, we have already seen the students' perception towards English teaching stimulus variation skills through their answers in every item for each indicator.

The first indicator that is voice variation, students perceive that the voice of English teacher in teaching is more clearly heard (61\% very often), often explains the material with different tone of voice $(43 \%)$ and rarely explains the material quickly (48\% sometimes). It means that voice of English teacher in teaching is varies greatly with frequency "very often" at 28 participants or $61 \%(+)$. In addition, teachers need to defend the quality of their voice capability in order to support their good performance while teaching and learning process. Therefore, students will able to understand the material by supported voice from teachers, and finally they will understand all the given material by clearly voice from teacher.

Secondly is focusing, the students perceive that the English teacher sometimes taps on the table or board to get students' attention (46\%), never deliberately says the wrong words to attract students' attention (33\%) and always cares about the noisy students (65\%). It means that the ability of English teacher in focusing is varying with 30 participants or $65 \%$ of always cares about the noisy students. From the statement before, it can be understood that teacher's expression facing noisy condition needs to 
be a mature ways, it means the teacher is able to giving constructive comment or advise for students who create a noisy condition in order to educate them and giving them a rule.

Thirdly is pausing. The students perceive that the English teacher is sometimes quite for a moment until students orderly (35\%), often gives students an opportunity to think for a while when they are given questions $(65 \%)$ and sometimes urges students to answer questions immediately (52\%). It means that the frequency is "often" provides an opportunity for students to think for a moment when giving questions with 30 participants (+) or $65 \%$. So, the teachers use pauses or 'wait time' after asking a question allows pupils to organize more complete answers. It can be concluded that English teacher's ability in pausing is varied.

The fourth is an eye contact. The students perceive that the English teacher often looks at students without picking (41\%), when explaining the material, the viewpoint of the English teacher is sometimes more focus on the book or board $(48 \%)$ and often looks at students in all directions (46\%). It can be concluded that English teacher's ability in eye contact is vary. It means that teacher need to improve their eye contact towards students in order to build up the relationship with students and control the class activity while teacher explains the material with frequency teacher "sometimes" more focused on the book or board at 22 participants (-).

The fifth indicator is gesturing. The students perceive that while explaining the material, English teacher sometimes raises or waves his or her hand or moves the eyebrows (35\%). English teacher's body movements are sometimes adjusted to the subject matter (30\%) and never teach rigidly (70\%). It means that English teacher's ability in gesturing is vary with frequency "never" teaches rigidly at 32 participants. From that fact, the teachers must control those ways to be an educate ways, such as: verbal communication and non-verbal communication, for example: teachers must be able mention the name of students that bother the situation in order to remind students to less their noisy.

The sixth indicator is movement. The students perceive that English teacher often explains the material while walking around the classroom (37\%), teacher sometimes has a sit in his chair while explaining the material (46\%) and the teacher very often approaches the students and sees the work / assignments made by students (54\%). It means that the ability of English teacher in movement is vary with frequency "very often" approaches the students and sees the work / assignments made by students at 25 participants (+). This is a good thing for teacher performance if in need, students' will be interested in classroom with that gesture if teachers are communicative and make students enthusiast without getting boring or confused.

In line with those results above, it is integrated the Components of Stimulus Variations Skills as states by (C. Turney et al 1983:115). From 6 variations of skills, it is found 5 skills are positive, there are: Voice Variation, Focusing, Pausing, Gesturing and Movement and it is found a skill which is negative, there is: Eye Contact. The result is negative in a variation before defining a factor based on Turney (1983) divided into: 1) Eye Contact: By fixing his / her gaze on inattentive pupils the teacher can gain their 
attention or by shifting eye contact, gauge pupil interest and understanding.

Finally, from the several discussions above, we know that English Teacher needs to improve their capability as an English Teacher and as an educator. By that the quality of teaching and learning process will show an improvement and always understand learners' types as the primary factor to teach them in school.

\section{CONCLUSION}

The conclusion is among the six indicators, there are five indicators namely voice variation, pausing, eye contact, gesturing and movement show that English teacher is vary in teaching style while one other indicator that is focusing is less varied.

In first indicator, teacher's voice is very clearly. Teachers need to defend the quality of their voice capability in order to support their good performance while teaching and learning process. Therefore, students will able to understand the material by supported voice from teachers, and finally they will understand all the given material by clearly voice from teacher.

In second indicator, the teacher cares about noisy student. Teachers' expression facing noisy condition needs to be a mature way, it means the teacher is able to giving constructive comment or advise for students who create a noisy condition in order to educate them and giving them a rule.

In third indicator, the teacher provides an opportunity for students to think for a moment when given questions. Teachers would be kept on the track about their professionalism in classroom, and they must able to encourage students to ask with many kinds of motivation and approach.

In fourth indicator, teacher's view is more on the book or board. Teacher needs to improve their eye contact towards students in order to build up the relationship with students and control the class activity while teacher explains the material.

In fifth indicator, the teacher never teaches rigidly. The teachers must control those way to be an educated way, such as: verbal communication and non-verbal communication, for example: teachers must be able mention the name of students that bother the situation in order to remind students to less their noisy.

In sixth indicator, the teacher approaches the students and sees the work or assignment made by students. This is a good thing for teacher performance if in need, students' will be interested in classroom with that gesture if teachers are communicative and make students enthusiast without getting boring or confused.

\section{REFERENCES}

Aprilya. Kristina Nike. 2006. The Analysis of Speech Produced by Teacher and Students of Sixth Year Class of SDN Dawungsari. Semarang: Semarang State University.

Asril, Z. 2017. Micro Teaching. Edisi Kedua. Rajawali Pers. Jakarta.

Borgin, Simon. 2018. Teacher Evaluation: Global Perspectives and Their Implications for English Language Teaching a Literature Review. London: British Council.

Callahan J.P and Leonard H.C. 1982. Teaching in the Middle and Secondary Schools. New York: Macmillan Publishing Co. 
Hampp, PL. 2019. Use of Songs in Teaching Simple to be and Past Tense Teaching. Journal of English Language and Literature Teaching 4 (1).

Karwati. E \& Priansa D.J. 2015. Manajemen Kelas. Bandung: Alfabeta.

Liando, Nihta V F. 2009. Language Policy and English Language Teaching in Indonesian and Thai Primary Schools. E-CLUE, Vol3, No 1.

Mogea, T. 2019. The Effectiveness of Question and Answer Technique in Teaching Reading Comprehension at SMP Negeri 3 Ratahan. Journal of Educational Method and Technology, 2(2).

Neufeldt, V. 1996. Webster's New World College Dictionary. Third Edition. USA: Mc. Millian Inc.

Panambunan E, Tulung GJ, Maru MG. 2016. Improving Students' Speaking Skill Ability Through Communicative Language Teaching of The Second Level Students at MEC Megalia English Course. Journal of English Language and Literature Teaching 1 (01).

Papalia, E.D \& S. Olds Wendkos. 1985. Psychology. Second Edition New York: Mc.Graw Hill.

Sudjana, N. 2006. Penilaian Hasil Proses Belajar Mengajar. Bandung: PT. Remaja Rosdakarya.

Suharsimi, A. 2014. Prosedur Penelitian Suatu Pendekatan Praktek. Jakarta: PT. Rineka Cipta.

Tuilan J, Tuerah JIC, Mewengkang A, Paat W, Mege RA. 2018. English Teacher Efforts to Improve Students' Listening Ability: A Study at Don Bosco Catholic Junior High School Tomohon. $1^{\text {st }}$ International Conference on Social Science (ICSS 2018).
Turney, C. et al. 1983. Sydney Micro Skills Redeveloped. Sydney: Sydney University Press.

Wahidiyati, I. 2009. The Teachers' Teaching Style Variations in the English Classroom Activities: A Study on The English Teachers of SMPN 2 Ambarawa. Semarang: Unpublished "Skripsi" UNNES.

Walgito, B. 2003. Pengantar Psikologi Umum. Andi offset.

Walklin, L. 1982. Instructional Techniques \& Practice. England: Stanley Thornes. 